\title{
Central Giant Cell Granuloma
}

Nilotpol Kashyap ${ }^{1,}$, , Manisha Upadhyay ${ }^{2}$, Rupam Tripathi ${ }^{3}$, Pallavi Pawar ${ }^{4}$, Ranjeet Kumar Prasad Sah ${ }^{5}$, Rupesh Kumar Mandal ${ }^{6}$

${ }^{1}$ Professor and Head, Department of Pedodontics and Preventive Dentistry, Universal College of Medical Sciences, Bhairahawa, Nepal

${ }^{2}$ Lecturer, Department of Pedodontics and Preventive Dentistry, Universal College of Medical Sciences, Bhairahawa, Nepal

${ }^{3}$ Lecturer, Department of Conservative Dentistry and Endodontics, Universal College of Medical Sciences, Bhairahawa, Nepal

${ }^{4}$ Senior Lecturer, Department of Pedodontics and Preventive Dentistry, Pacific Institute of Dental Sciences, Udaipur, India

${ }^{5}$ Intern, Universal College of Medical Sciences, Bhairahawa, Nepal

${ }^{6}$ Intern, Universal College of Medical Sciences, Bhairahawa, Nepal

*Corresponding Author : Dr. Nilotpol Kashyap, Professor and Head, Department of Pedodontics and Preventive Dentistry, Universal College of Medical Sciences, Bhairahawa, Nepal, Tel: +977 9811596307; E-mail: nilkash9365@gmail.com

Received date : April 26, 2019; Accepted date : June 07, 2019; Published date: June 07, 2019

Citation: Kashyap N, Upadhyay M, Tripathi R, Pawar P, Sah RKP, et al. (2019) Central Giant Cell Granuloma. J Dent Oral Maxillofac Surg 2(2): dx.doi: 10.31579/2643-6612/010

Copyright : (c) 2019 Kashyap N. This is an open-access article distributed under the terms of The Creative Commons Attribution License, which permits unrestricted use, distribution, and reproduction in any medium, provided the original author and source are credited.

\section{Introduction}

Central giant cell granuloma (central giant cell granuloma) is an uncommon benign bony lesion that occurs in the mandible and maxilla and accounts for approximately $7 \%$ of all benign tumours of the jaws [1]. The World Health Organization (WHO) has defined central giant cell granuloma as an intraosseous lesion consisting of cellular fibrous tissue that contains multiple foci of haemorrhage, aggregations of multinucleated giant cells and occasional trabeculae of woven bone [2]. Central giant cell granuloma occurs predominantly in children or young adults, with approximately $75 \%$ of cases presenting before 30 years of age although presentation can occur at any age [3]. Females are affected more frequently than males, with a ratio of 2:1 [4].

The clinical behaviour of central giant cell granuloma ranges from a slow growing asymptomatic swelling to an aggressive lesion that presents pain, local bone destruction, root resorption or tooth displacement [5].

\section{Clinical Relevance}

Chuong et al. [6] outlined the criteria that can be used to classify a lesion as aggressive or non-aggressive. Aggressive lesions are characterized by one or more of the following features: pain, paraesthesia, root resorption, rapid growth, cortical perforation, and a high recurrence rate after surgical curettage. Different authors have classified central giant cell granuloma into two types, based on clinical and radiographic features [5].

Aggressive lesions are mostly found in younger patients. Histologically there is no strict criterion to differentiate between aggressive and non-aggressive lesions, however the number and volume of giant cells versus other components of the lesion might give an indication on its clinical behaviour [7].

Surgery is considered the traditional treatment and it is still the most accepted one, however in literature not all authors agree on the type of surgery which should be performed. Excision via curettage has been associated with a low rate of recurrence for what concerns small lesions. In case of recurrences, curettage plus peripheral osteotomy and bone resection should be performed instead [7]. Unal et al. proposed obtaining safety margins by means of microdrilling of the surgical field with a diamond burr [8]. Although en bloc resection is the treatment which provides the lowest recurrence rate, only a few single case reports describe the use of this technique followed by reconstruction with iliac crest graft [7].

Non-surgical treatments (alpha interferon [a-IFN], calcitonin, corticosteroids) have been described and their benefits may be worthy of consideration.
As pointed out by de Lange medical therapy success rates are still not reaching those of surgery in controlling the lesions and additional surgery is undoubtedly needed whenever medical therapy fails [9].

\section{Case Report}

An 8 year old boy reported to the Department of Pedodontics and Preventive Dentistry, Rungta College of Dental Sciences \& Research, Bhilai, Chhattisgarh with a chief complaint of swelling in upper front region of the mouth for the last 20 days, with a history of sudden increase in size since one week. Associated with swelling there was no history of pain or bleeding. On intra oral examination, a $1.5 \times 1.5 \mathrm{~cm}$, well defined oval, reddish pink, soft, non-tender, extending toward the palatal surface between the two central incisors. Diastema was present with respect to teeth 11 and 21. There was no associated lymphadenopathy. [Figure 1 showing preoperative view of patient; Figures $2 \mathrm{a}$ and $2 \mathrm{~b}$ Showing the central giant cell granuloma].

Figure 1: Showing preoperative view of patient.

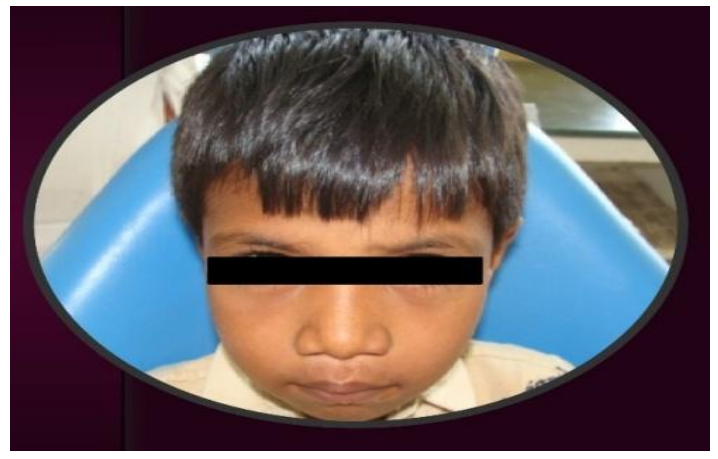

Figure $\mathbf{2 a}$ and $\mathbf{2 b}$ : Showing the central giant cell granuloma.
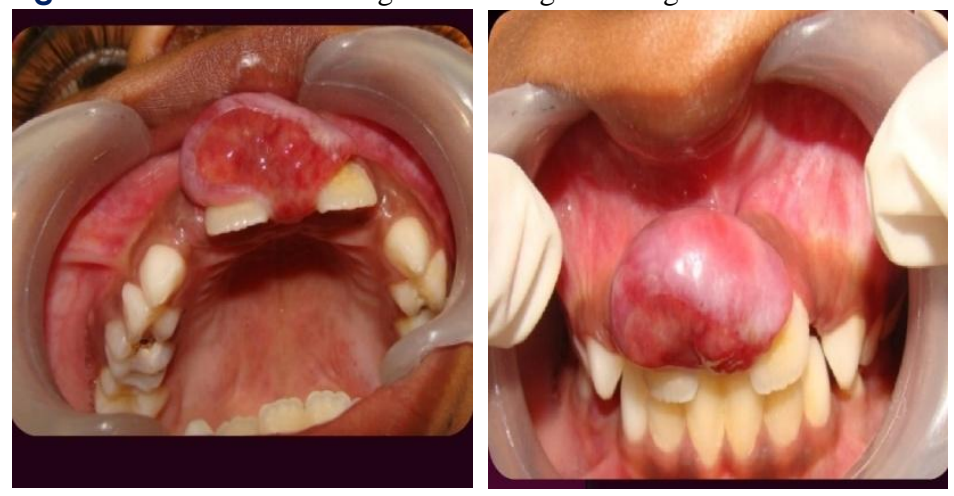
No systemic abnormalities were detected. Hematological reports were noncontributory. A decision was thus made to excise the lesion. The growth was excised under local anesthesia with a cold scalpel. Care was taken to remove the entire base and the excised lesion was stored in $10 \%$ formalin and sent for histopathological examination. [Figure 3: Showing excisional biopsy].

Figure 3: Showing excisional biopsy.

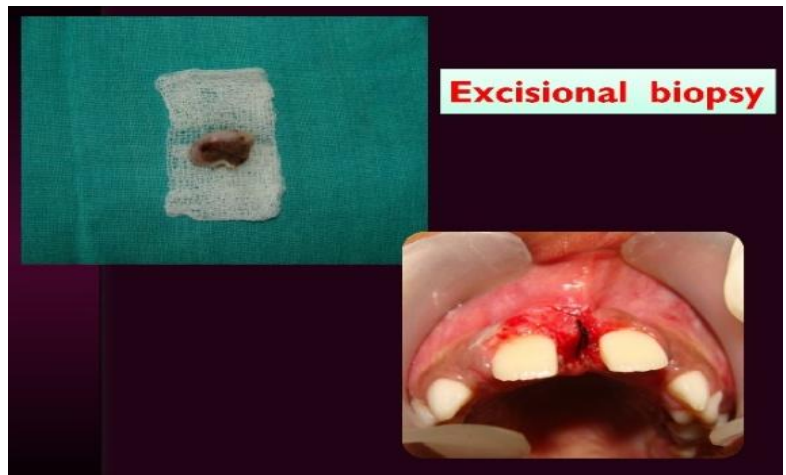

The histopathological section showed well encapsulated lobulated mass, numerous giant cells and hyperparakeratinized stratified squamous epithelium. The presence of these features was suggestive of central giant cell granuloma. The lesion reoccurs during $2^{\text {nd }}$ week and $3^{\text {rd }}$ month follow-up period and was retreated. The lesion did not reoccur during the 1-week and 6-month follow-up period. (Figures 4a and $4 \mathrm{~b}$ Showing histopathological view); (Figures 5a-5e Showing retreatment of the recurrent central giant cell granuloma), (Figure 6 Showing postoperative view after retreatment).

Figure 4a and 4b: Showing histopathological view.
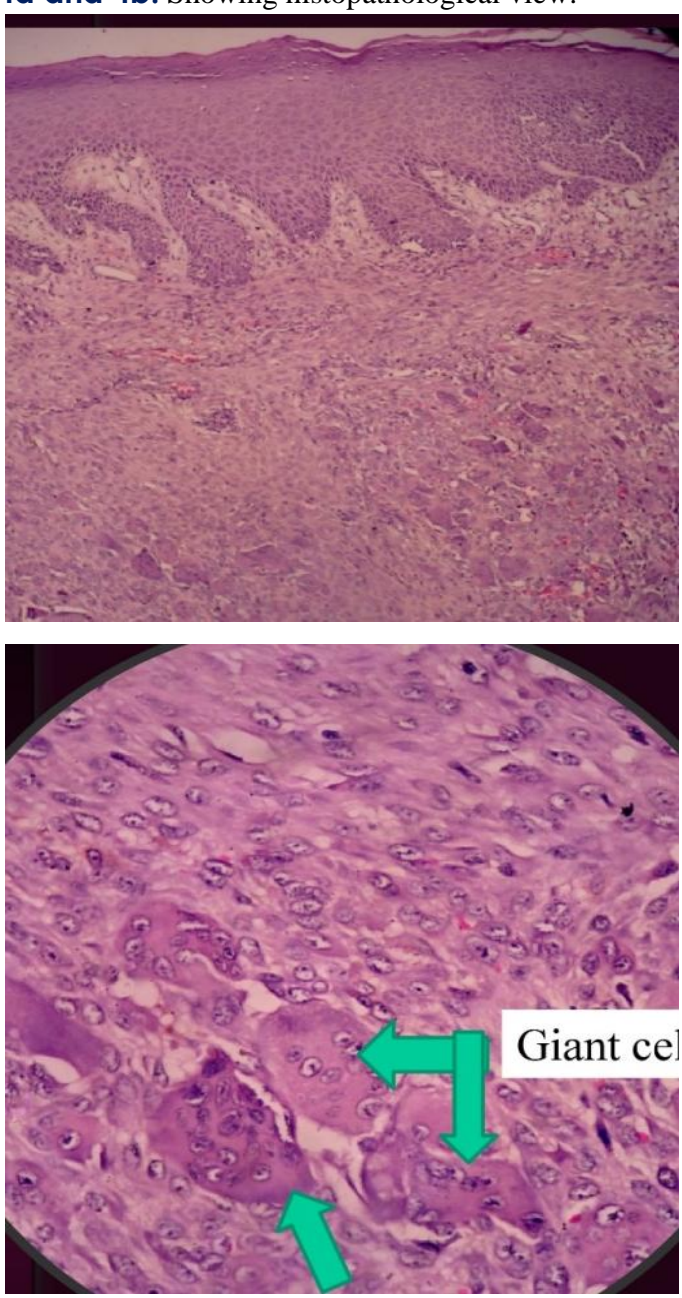

Figure 5a-5e: Showing retreatment of the recurrent central giant cell granuloma.
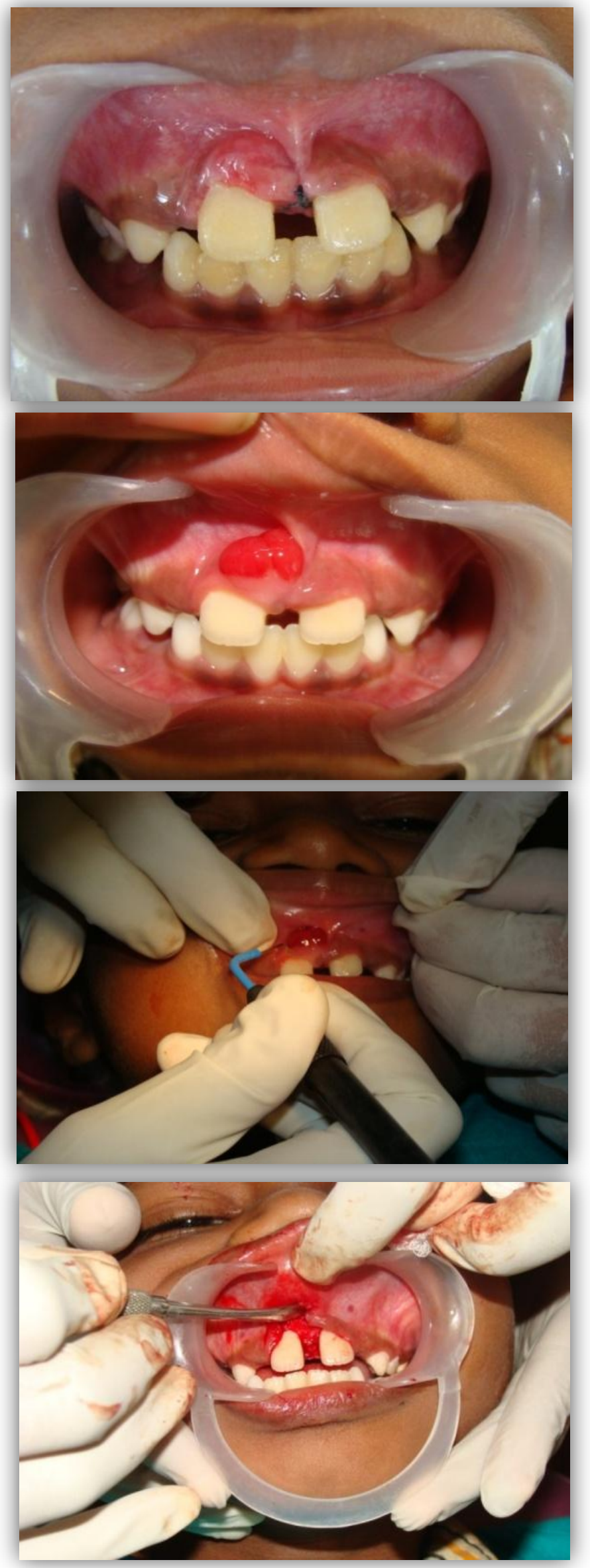


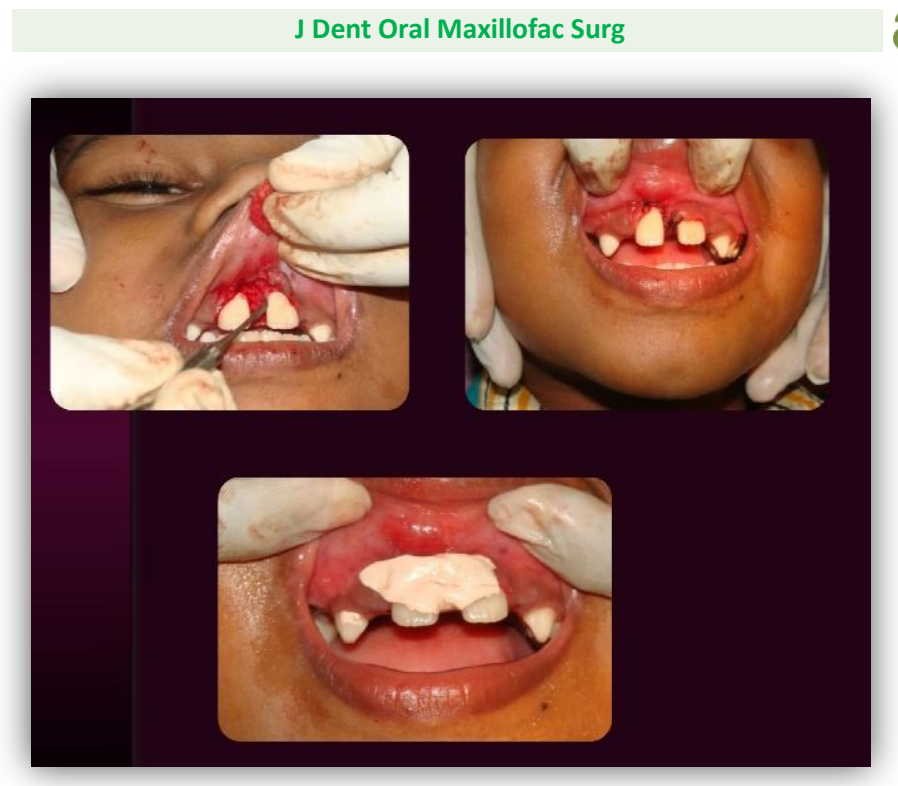

Figure 6: Showing postoperative view after retreatment.

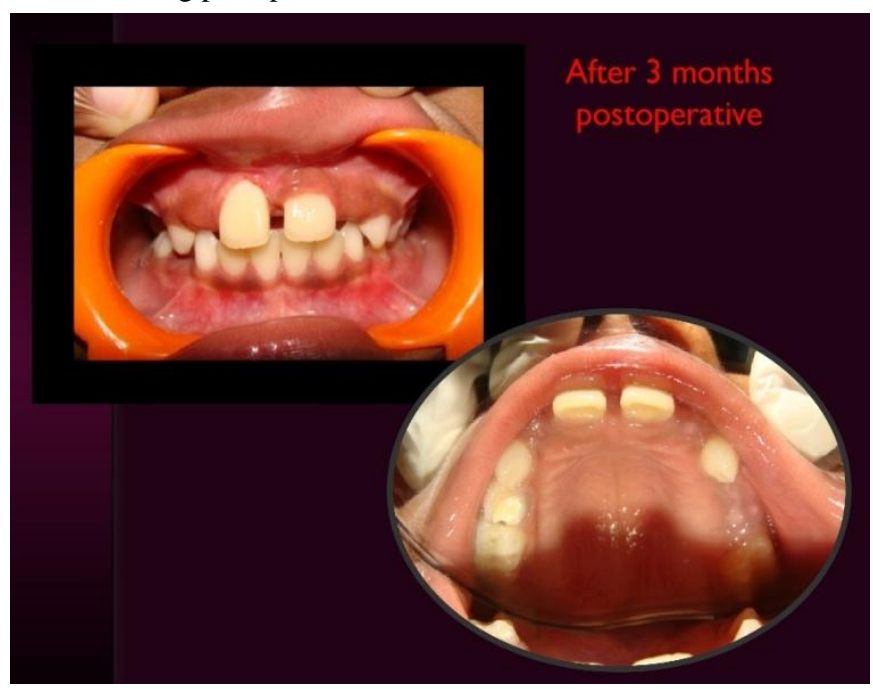

Table 1: Results: surgical therapy

\begin{tabular}{|l|l|l|l|l|l|}
\hline Author & No. & $\begin{array}{l}\text { Aggressive/ non- } \\
\text { aggressive }\end{array}$ & treatment & Follow-up & $\begin{array}{l}\text { Overall } \\
\text { rate }\end{array}$ \\
\hline Chuong (1986) [6] & 17 & $8 / 9$ & $\begin{array}{l}\text { recurrence } \\
\text { therapy in 4 patients }\end{array}$ & $41.0 \%$ \\
\hline Eisenbud (1988) [20] & 37 & -- & $\begin{array}{l}\text { Curettage and } \\
\text { resection }\end{array}$ & 2-16 years & $11.0 \%$ \\
\hline Whitaker (1993) [3] & 47 & $26 / 21$ & Curettage & Mean 48 months & $49.0 \%$ \\
\hline Bataineh (2002) [21] & 18 & $18 / 18$ & Resection & 1-9 years & $5.6 \%$ \\
\hline Kruse-Losler (2006) [22] & 26 & $10 / 16$ & $\begin{array}{l}\text { Curettage and } \\
\text { resection }\end{array}$ & 9 months to 12 years & $11.5 \%$ \\
\hline Tosco (2008) [7] & 18 & $11 / 7$ & Resection (.5 mm) & Mean 68 months & $0 \%$ \\
\hline
\end{tabular}

\section{Background}

Various authors proposed excision via curettage and the overall recurrence rate has been reported to range from $16 \%$ to $49 \%$ [3,6]. A higher incidence of recurrence was found in aggressive central giant cell granulomas and in younger patients, especially males. According to Eisenbud et al., in case of recurrence curettage plus peripheral ostectomy and bone resection should be performed [20]. Unal et al. proposed to obtain safety margins by means of microdrillingof the surgical field with a diamond burr [8]. However Eisenbudet al. [20] indicate that surgical curettage with peripheral osteotomy is still not the safest treatment for central giant cell granulomas, especially in aggressive lesions. En bloc resection might provide the greatest certainty of a cure: in a study of 18 patients with aggressive central giant cell granuloma, treatment consisted of en bloc surgical resection with a $5 \mathrm{~mm}$ margin of healthy tissue and only 1 patient had a recurrence [21].

In growing patients, aggressive surgical approaches are not a suitable solution for central giant cell granulomas. More conservative surgery is instead the only applicable strategy for subjects with deciduous dentition. In general destructive surgery (en bloc surgical resection with $5 \mathrm{~mm}$ margins) seems to be the safest option for the control of recurrences but it may result in facial deformities which are obviously of great concern.

\section{Conflict of Interest: None}

\section{References}

1. Austin LT, Dahlin CD, Royer RQ (1959) Giant cell reparative granuloma and related conditions affecting the jawbones. Oral Surg Oral Med Oral Pathol 12: 1285-1295.

2. Barnes L, Eveson JW, Reichart P, Sidransky D (2005) Pathology and genetics of head and neck tumours. In: Kleihues P, Sobin LH, World Health Organization classification of tumours. Lyon, France: IARC Press.
3. Whitaker SB, WaldronCA (1993) Central giant cell lesions of the jaws. A clinical, radiologic, and histopathologic study. Oral Surg Oral Med Oral Pathol 75(2): 199-208.

4. de Lange J, van Rijn RR, van den Berg H, van den Akker HP (2008) Regression of central giant cell granuloma by a combination of imatinib and interferon: a case report. Br J Oral Maxillofac Surg 47(1): 59-61.

5. Stavropoulos F, Katz J (2003) Central giant cell granulomas: a systematic review of the radiographic characteristics with the addition of 20 new cases. Dentomaxillofac Radiol 31(6): 213-217.

6. Chuong R, Kaban LB, Kozakewich H, Perez-Atayde A (1986) Central giant cell lesions of the jaws: a clinicopathologic study. J Oral Maxillofac Surg 44(9): 708-713.

7. Tosco P, Tanteri G, Iaquinta C, Fasolis M, Roccia F, et al. (2009) Surgical treatment and reconstruction for central giant cell granuloma of the jaws: A review of 18 cases. J Craniomaxillofac Surg 37(7): 380-387.

8. Unal M, Karaback T, Vayisoglu Y, Bagis HE, Pata YS, et al. (2006) Central giant cell reparative granuloma of the mandible caused by a molar tooth extraction: special reference to the maneuver of drilling the surgical field. Int J Pediatr Otorhinolaryngol 70(4): 745-748.

9. de Lange J, van den Akker HP, van den Berg H (2007) Central giant cell granuloma of the jaw: a review of the literature with emphasis on therapy options. Oral Surg Oral Med Oral Pathol Oral Radiol Endod 104(5): 603-615.

10. Vered M, Buchner A, Dayan D (2006) Giant cell granuloma of the jaw bones the proliferative vascular lesion? Immunohistochemical study with vascular endothelial growth factor and basic fibroblast growth factor. J Oral Pathol Med 35(10): 613-619.

11. Kaban LB, Troulis MJ, Ebb D, August M, Hornicek FJ, et al. (2002) Antiangiogenic therapy with interferon alpha for giant cell lesions of the jaws. J Oral Maxillofac Surg 60(10): 1103-1111. 
12. Kaffe I, Ardekian L, Taicher S, Littner MM, Buchner A (1996) Radiologic features of central giant cell granuloma of the jaws. Oral Surg Oral Med Oral Pathol Oral Radiol Endod 81(6): 720726.

13. Jacoway JR, Howell FV, Terry BC (1988) Central giant cell granulomadan alternative to surgical therapy. Oral Surg Oral Med Oral Pathol 66: 572.

14. Flanagan AM, Nui B, Tinkler SM, Horton MA, Williams DM (1988) The multinucleate cells in giant cell granulomas of the jaw are osteoclasts. Cancer 62(6): 1139-1145.

15. Nickolson GC, Horton MA, Sexton PM, Mosely JM, Kemp BE, et al (1987) Calcitonin receptors of human osteoclastoma. Horm Metab Res 19: 585-589.

16. Harris M (1993) Central giant cell granulomas of the jaws regress with calcitonin therapy. Br J Oral Maxillofac Surg 31(2): 89-94.

17. Kaban LB, Mulliken JB, Ezekowitz RA, Ebb D, Smith PS, et al. (1999) Antiangiogenic therapy of a recurrent giant cell tumor of the mandible with interferon alfa-2a. Pediatrics 103(6): 11451149 .
18. Borges HO, Machado RA, Vidor MM, Beltrao RG, Heitz C, et al. (2008) Calcitonin: a non-invasive giant cells therapy. Int J Pediatr Otorhinolaryngol 72(7): 959-963.

19. Terry BC, Jacoway JR (1994) Management of central giant cell lesions: an alternative to surgical therapy. Oral Maxillofac Surg Clin N Am 6: 579-601.

20. Eisenbud L, Stern M, Rothberg M, Sachs SA (1988) Central giant cell granuloma of the jaws: experiences in the management of thirtyseven cases. J Oral Maxillofac Surg 46(5): 376-384.

21. BatainehAB, Al-Khateeb T, Rawashded MA (2002) The surgical treatment of central giant cell granuloma of the mandible. J Oral Maxillofac Surg 60(7): 756-761.

22. Kruse-Losler B, Diallo R, Gaertner C, Mischke KL, Joos U, et al. (2006) Central giant cell granuloma of the jaws: a clinical, radiologic, and histopathologic study of 26 cases. Oral Surg Oral Med Oral Pathol Oral Radiol Endod 101(3): 346-354. 